BMC JOURNAL OF SCIENTIFIC RESEARCH

A Multidisciplinary Peer Reviewed Research Journal

ISSN: 2594-3421 (Print), 2773-8191 (Online)

\title{
Resistance through Female Bonding in Tehmina Durrani's Blasphemy
}

\author{
Mukti Nath Kandel*
}

muktinkande143705@gmail.com

Received: Sept. 30, 2021, Accepted: Dec. 15, 2021

\begin{abstract}
The present research article analyses the suffering of women and their resistance against oppressive Islamic patriarchy through female bonding in Tehmina Durrani's Blasphemy. In doing so, it offers the working definition of the term "feminism" as a tool of inquiry. It mainly focuses on the suffering of Heer, the protagonist of the novel, due to her loveless marriage with Pir Sain. It exposes the easy distortion of Islam by so-called hypocritical religious leaders like Pir Sain. The suffering of Heer and other female characters in the novel reveal the problems in the cultural and social setting of the Islamic culture and religion. Heer is repeatedly beaten, raped and humiliated by her abusive husband Pir. Pir forces her to live in the world that he has constructed for her. Her marriage with Pir utterly fails as it turns out to be a source of trouble and repression of her self-satisfaction. When she fails to tolerate severe torture and domestic violence, she decides to revolt against it. This paper concludes that Heer is able to resist sexual abuse and exploitation through female bonding. In doing so, she is able to assert her female selfhood.
\end{abstract}

Key words: Blasphemy, female bonding, patriarchy, Islam, female selfhood

\section{Introduction}

Tehmina Durrani's novel Blasphemy portrays the suffering of the protagonist Heer and other female characters. They are bound to suffer due to oppressive Islamic patriarchy and as such dare to develop female bonding to resist patriarchy. The novel is written in flashback technique. It begins with the demise of Heer's husband Pir Sain and ends with the staged death of the protagonist Heer. Heer recalls her past life only after the death of Pir Sain. She describes her marriage with Pir Sain, a religious person in rural Pakistan who is double in her age. Her mother compels Heer to marry Pir against her wishes in order to restore wealth and happiness for the rest of the family.

Heer's marriage fails and proves a curse for her. She faces difficulties in learning culture, rituals, norms and values of her husband's house. The novel successfully depicts the suffering of Heer because of her loveless marriage with Pir Sain. She is frequently humiliated and severely beaten by her husband in front of all family members and maid servants. Her husband exercises his religious power over his innocent wife at home. She is, therefore, victimized by Islamic culture, religious hypocrisy and sexual

\footnotetext{
* Mr. Kandel is a Teaching Assistant of English at Birendra Multiple Campus (Tribhuvan University)
} 
abuse. Suffering silently for several years, Heer, finally, dares to cross the cultural boundaries ignoring the dire consequences. Because of her revolt against sexual abuse and exploitation, she is made a real blasphemous.

Suffering of Heer in the novel reveals the deplorable condition of married women in rural Pakistan. No one listens, cares and helps her. Her husband becomes a great enemy throughout her married life. She becomes the victim of sexual abuse and religious hypocrisy at the hand of her own husband. Her dreams of happiness end when she enters Pir's haveli (mansion). She finds the religious hypocrisy of her husband Pir Sain. Pir who pretends to be the man of God is a demon by nature. He conceals his crimes in the name of Allah. The shrine is a domain of his evilness. The system of inheritance leads him to be the head of the shrine. Though he is a Holy Pir in his locality, he tortures and sexually abuses his wife in every possible way. Pir rapes his wife daily and humiliates her without sufficient reasons. Heer is beaten, humiliated, abused, raped and forced to live in the confined world of haveli. She struggles a lot to resist oppressive patriarchy and gains support from other women through female bonding. In doing so, she is able to assert her identity despite her cultural limitations.

Several scholars have studied, analysed and interpreted this novel from various perspective since its first publication in 1998. Due to the powerful depiction of the sexual abuse, domestic violence and religious hypocrisy faced by Pakistani women, the novel has drawn substantial amount of critical interpretations. Iftikhar (2006) mentions that the story of this novel is not against Islamic society but "it is simply against the exploitation of religious feelings and fears of ignorant people by clergymen who are thought to be close to God and have special power to help people" (p. 31). Iftikhar argues that the story of Heer is not against Islamic society but against the exploitation of religious feelings and fears of ignorant people by the hypocritical clergymen. The corrupted clergymen like Pir Sain who claim to be close to God and have special power to help people contaminate the Islam. Another critic Saramango (1999) views that Blasphemy is the novel that severely criticizes divine Islamic Sanction:

But there is nothing remotely funny about Blasphemy, by Pakistani novelist Tehmina Durrani, a blistering attack on an institution with divine Islamic Sanction- the hereditary keepers of the shrines of Sufi Saints. Ordinarily venerated in Pakistan for their holiness, Durrani's keeper of the shrine is a murderous sadist. (p. 10 )

Saramango argues that the novel foregrounds the hidden reality of divine Islamic Sanction. It successfully depicts the corrupt Sufi Saint like Pir Sain who is a murderous sadist. Sufi Saints like Pir Sain tortures his wife and other women in every possible way. Though Sufi Saints are venerated in Pakistan for their holiness, Durrani's depiction of hypocritical saint like Pir Sain defames Islam.

Dirence's (2008) essay "Breaking Down the Walls: Challenging the Concept of Zenana in Blasphemy" is an insightful, thought-provoking discussion of the veiling practices in contemporary Muslim cultures and their implications. He asserts that 
"the Muslim Practice of veiling and the actual fabric of the veil itself, functions as an ambiguous curtain at best, a curtain that reveals and conceals simultaneously in order to render femininity invisible while making visible the female in the "public domain"" (p. 9). He argues that the veil itself is the site of negotiation between intense seclusion and complete exposure. Though Heer may wish to dismantle the actual wall that imprisons her, she cannot reject the covering of her face completely.

The novel is quite powerful in terms of its structure, setting, perfect characterization etc. My concern, however, in this article is to analyse the suffering of women in the oppressive Islamic patriarchy through the perspective of feminism. For this purpose, I will rely on some of the prominent critics such as Simone de Beauvoir and Helene Cixous from the vast feminist criticism. This article mainly concerns the suffering of the protagonist Heer and the way she resists oppressive Islamic society. She gains support of other female characters through female bonding to challenge oppressive patriarchal society of Pakistan in order to affirm her female selfhood.

\section{Subjugation of Women and Sense of Female Bonding in the Novel}

The novel is set in rural Pakistan. The plot of this novel mainly focuses on suffering of Heer, the protagonist of the novel. It exposes the distortion of Islam by predatory religious leaders like Pir Sain. Heer is bound to suffer terrible events in her conjugal life because of oppressive Islamic tradition and culture. Through the depiction of Heer and her suffering that is imposed on her by her patriarchal society, Durrani deals with the suffering of women in Pakistani society. Excessive subjugation evokes sense of resistance in their mind. The novelist basically emphasizes on the predicament of an individual woman in Pakistani society amidst the absurdities of cultural and ritual paradigms. These difficulties are imposed on innocent characters like Heer whose feeling and voices are suppressed by her society in the name of existing tradition and culture. Although she is a tolerant and submissive housewife, she is terribly frustrated by her marriage with Pir Sain. She sacrifices her identity and individuality for the success of her marriage. However, she suffers from intense isolation when her husband neglects her love.

Women in Pakistani society are still assigned traditional gender roles. Heer represents Pakistani women in general and a Pakistani woman in particular who is victimized by sexual abuse, and religious hypocrisy. The submissive woman like Heer suffer from the sense of isolation as there is no one to share her grief. This is exactly true in Durrani's Blasphemy. The identity of a woman is generally connected to and defined by societal and cultural norms and values. Her identity is defined only in relation to man as she lacks an identity of her own. Beauvoir (1975) asserts it in a right way in her text The Second Sex: "One is not born, but rather becomes, a woman" (p. 295). Beauvoir asserts that gender identity is merely a social construct and therefore it can be changed. Heer lacks the identity of her own in the novel. As she lacks agency, her identity largely depends on her relation to her abusive husband who represents oppressive Islamic patriarchy. 
Heer is the mouthpiece of the writer to express her views about woman and their deplorable condition in Pakistani society. Concerning the agency of woman Cixous (1994) rightly argues: "Woman must write herself: must write about women and bring women to writing, from which they have been driven away as violently as from their bodies" (p. 78). In this context, writing the story of Heer is significant not just, because she is driven away from her mother's embrace but also from her own body.

Heer suffers identity crisis in both personal and marital affairs. She serves her husband but utterly fails to get love and affection from him. Her husband behaves her like a demon. She endures all pains though she is severely beaten by her husband in front of all the family members and her maid servants. No one listens, cares and helps her. She tolerates the various sorts of psychological, emotional and physical stress that is inflicted upon her by her husband. On the very night of their marriage Pir Sain tortures and humiliates her mercilessly. He hovers upon her with animal haste against her will all the time. She dies each and every night except three nights of her safe period. He seduces her as if she is a sex object made for him. She faces humiliation one after another in her life. When she notices the illicit relationship between Kaali and Pir Sain, she tries to resist it but Pir Sain kicks her and humiliates her further. All these events lead her towards madness and psychosis.

Heer becomes victim of oppressive Islamic patriarchy and culture. She is forced to live in confinement: "The drapes were never drawn aside. The windows were never opened. It was always dark. There was no sign of the day. The lights came on as soon as the early morning alarm shrieked. Here, it was always night" (p. 44 ). She does not have the sense of personal freedom. Her abusive husband treats her like a prostitute. The dark room suggests the commodification of female body. Her acute suffering in her confinement proves the pathetic condition of women in oppressive patriarchal society. She cannot marry the man of her choice because of traditional norms and values. Her mother compels her to marry Pir Sain because of poverty. Pain and suffering of various sorts due to oppressive patriarchy repeatedly overwhelm her.

When Heer cannot tolerate the excessive pain that is inflicted upon her by her husband, she dares to speak and resist oppressive Islamic patriarchy. Concerning the true emancipation of women, Goldman (1911) rightly asserts:

History tells us that every oppressed class gained true liberation from its masters through its own efforts... It is, therefore, far more important for her to begin with inner regeneration, to cut loose from the weight of prejudices, traditions, and customs. (p. 231)

Goldman argues that true emancipation and regeneration of women is possible when they dare to challenge existing prejudices, traditions and customs that places women as inferior creature. As suggested by Goldman, Heer even decides to kill her abusive husband to assert her true emancipation.to resist oppressive Islamic patriarchy. Heer sounds like a rebel figure when she frankly declares: 
To me, my husband was my son's murderer. He was also my daughter's molester. A parasite nibbling on the Holy Book, he was Lucifer, holding me by the throat and driving me to sin every night. He was Bhai's destroyer, Amma Sain's tormentor, Ma's humbler and the people's exploiter. He was the rapist of orphans and the fiend that fed on the weak. But over and above all this, he was known to be the man closest to Allah, the one who could reach Him and save us. (p. 143)

Heer's retelling about Pir Sain shows that he was a murderer and molester in a literal sense. Pir Sain had sexual intercourse with many women outside the marriage institution and killed the foetus if they got pregnant. Besides, he molested girls of his daughters' age and even illegitimate daughters by women who were working for him in his haveli. Although he claims to be closer to the Allah, Pir violates the basic religious principle of Islam and commits several social crimes. Regarding the position of women in Islamic society, Hasan (1981) argues that "equality in the role and status in Islam has been ensured and dealt comprehensively within the framework of rights and privileges in an Islamic society" (p. 68). Hasan advocates for gender equality to ensure fundamental human rights in Islamic society. On the contrary to this concept of Hasan, the corrupt religious leaders like Pir Sain defame Islam. Pir's religious hypocrisy becomes obvious when he cheats on innocent people who honour him.

Heer does have potentials to express her anger and aggression like that of male characters especially her husband, and her son. Their brutal behaviour and domination persist over women because women remain silent as long as they can tolerate. Heer questions religious books and the Shrine- symbol of religion. She suspects the entire institution that is unfair and partial. She questions to the Almighty why there is injustice upon the helpless and poor. Concerning the wrong interpretation of Islam, Jawad (1998) in The Rights of Women in Islam argues:

Islam regards women to be equal to men as human beings; hence it emphasizes mutual understanding and respect between the two sexes. From the Islamic viewpoint, women as human beings and as half of the society should be treated with care, tenderness and affection. Indeed, the Prophet insisted on kind and gentle treatment of women and demonstrated this not only through his attitude towards his wives but also in his teachings to his followers. (p. 22)

When Heer realizes her individuality under threat, she begins to question the religious principles as well. She even questions the attitude of her own son, Rajaji who does not treat her as mother. Rather he treats her as a woman: "Rajaji stood over me and growled, 'She is a curse. She gave our family nothing but shame. I pray she dies before she can sting us like snake again" (p. 222). The relationship of Rajaji with Heer implies her subjugated position in the family. Even her own son does not respect her. This proves her bridal and maternal identity in crisis because of oppressive patriarchy .

Durrani tries to assert the phenomenal reality of the time through her protagonist 
Heer: "Amma Sain had been mistress of the Haveli for many years until I weaned away that burden. She had known everything and yet known little, or perhaps it was a feminine intelligence: she knew more than she let on" (p. 13). Amma pretends that she has been enjoying her life as a mistress of the Haveli. Heer focuses on her mother's innocent plight and tells much about the lives of women with feminine qualities. She claims that the way society looks at women is biased and unfair.

Durrani in this novel focuses on Heer's journey from a life of innocence and slavery to assertion of her female selfhood through female bonding. Heer and other women are silent as long as they can tolerate their suffering. Heer is not alone to challenge oppressive Islamic patriarchy. She gains support of other female characters to challenge patriarchy. The sense of female bonding is quite significant in the novel. In this regard, Beasley (1997) always stands in favour of woman to woman relation:

If men/masculinity is not to be inevitably valued and women/femininity is to be acknowledged, even celebrated, then woman to woman relationships can no longer be viewed as of marginal significance against women's relationship with men. In a social context in which women are commonly characterized as engaged in a war among themselves over men and incapable of sustained friendships with each other, womencentred feminists typically promote a counter-strategy in which woman to woman relationships are given credit and encouraged. (p. 49)

Beasley emphasizes on the core aspect of women-centred feminism. If feminism aims at reshuffling women's relation with men, the significance of woman to woman relation should not be ignored and marginalized. The collective sense of being the member of organized sisterhood is essential in reformulating man-woman relation in a new way.

Women in the Islamic societies are subjected to Islamic patriarchal norms and values. Patriarchy has used its weapon to dominate and control women but women resist such dominations and fight for the sake of their collective identity. Cheel is a female character who has responsibility to record each and every event conducted by Heer. Pir Sain in the name of Allah achieves political power and exercises cultural norms and values over Heer. Because of her continuous suffering and domestic violence, Heer finally kills her own husband but Cheel supports her to resist oppressive patriarchy through female bonding as she argues: "You were not ready before now bibiji" (p. 194). Though Cheel is kept by Pir Sain as a spy to watch and record various activities of Heer, she does not work for him. She acknowledges the tremendous suffering of Heer and therefore complains about delayed act of killing of Pir Sain. She becomes ready to kill Pir Sain to end Pir's exploitation of Islam and the misuse of Shrine's holiness for his own benefits.

Due to the sense of female bonding Amma Sain suggests her sister-in-law not to share anything to anyone: "You cannot trust anyone here. There is no one who will not inform Pir Sain of your actions" (p. 50). She suggests Heer not to reveal to any clues of actions taken by her. She develops group solidarity with Heer. She does not care about 
her relationship with her son Pir Sain and helps Heer in every possible ways to resist oppressive patriarchy.

Diya and Munni, the daughters of Heer, also support her mother through female bonding: "Our husbands beat us when we defend you. Why this is happening Amma?" (p. 207). Despite their suffering, they continue to support Heer. Another female character Sakhi Bibi encourages Heer to resist patriarchy. She asks Heer to read the translation of Quran and understand it properly. She wants to suggest Heer to expose the wrong interpretation of Quran by hypocritical religious and political leaders.

Feeling released from her confinement after the sad demise of her husband, she wants to unmask the secrets of the shrine with the help of an ex-servant girl, Tara. She plans to destroy the reputation of the dead Pir revealing the secret life of the holy Pir. She visits the men she had been introduced to as Piyari, revealing her identity as the Pir's wife. However, her plan fails completely. Her only form of escape ends in the staging of her own death with the help of her brother and her family. The novel ends with her visit to the (fake) shrine that has been erected in her name.

\section{Conclusion}

Durrani indirectly comments over the rigid Islamic culture that is based on the subjugation of women. Islamic patriarchy degrades the position of women and encourages men to impose their authority over women. The most prominent thing in the life of a woman seems to be her husband and she expects to have a husband who can take care of her in all aspects of her life. However, marriage becomes a nightmare and a source of sexual abuse in the life of Heer. Durrani enriches her characters especially Heer with the power to challenge oppressive patriarchy. This article concludes that Muslim culture is responsible for subjugation of women. All the female characters in the novel resist oppressive Islamic patriarchy through female bonding to support Heer's actions. Heer revolts when she loses happiness and right to lead her life independently. The suffering of women in Pakistan, thus, demonstrates the problems in the cultural and social setting of the Islamic culture and religion. Many Heers are bound to suffer and many Pirs are fated to die because of institutionalization of oppressive Islamic patriarchy.

\section{References}

Beasley, C. (1997). "Womanhood and Isolation". Feminisms. Ed. Kemp and Squire. New York: Oxford University Press.

Beauvoir, S. (1975). The Second Sex. Trans. H. M. Parsley. Harmondsworth: Penguin Books.

Cixous, H. (1994). The Laugh of the Medusa. The Woman and Language Debate.

Ed. Camlin Roman, et. al. USA: Rutgers University Press.

Dirence, D. (2008). "Breaking Down the Walls: Challenging the Concept of Zenana 
in Blasphemy." Women in Dialogue: (M) uses of Culture. Ed. Amber Fatima

Riaz, New Castle: Cambridge Scholar Publishing. 1-23.

Durrani, T. (1998). Blasphemy. Ferozsons (Pvt.) Ltd.

Goldman, E. (1911). Anarchism and Other Essays. Second Revised Edition. New York: Mother Earth Publishing Association. 219-231.

Iftikhar, A. (2006). Culture and Customs of Pakistan. Greenwood P.

Jawad, H. (1998). The Rights of Women in Islam. Macmillan Press Ltd.

Hasan, R. (1981). "The Role of Women as Agents of Change and Development in Pakistan”. Human Rights Quarterly. 3.3. 68-75.

Saramango, J. (1999). "Fiction Chronicle." Newsletter Committee on Intellectual Correspondence 3. 8-12. 